KLAEHN, F. U. and J. A. WINIESKI (1962): Interspecific hybridization in the genus Abies, Silvae. Genet. 11, 130-142.

KORMUTAK, A. (1992): Artificial hybridization between the white fir (Abies concolor Gord. et Glend./Lindl.) and grand fir (Abies grandis Dougl./Lindl.). Lesnictvi Forestry (Prague) 38, 759-769.

KoRMUTAK, A. (1997): Cytological aspects of interspecific hybridization in true firs (Abies species). In: BoRZAN, Z., Schlarbaum, S. E. (eds.), Cytogenetic studies of forest trees and shrub species Brijuni, Croatia, 8-11 September 1993. 303-310.

Lindgren, D. and R. YAZDANI (1988): Paternal contributions following artificial pollination in Pinus sylvestris (L.), Scand J Forest Res 3, 299-304.

LIU, T.-S. (1971): A Monograph of the genus Abies, Department of forestry, National Taiwan University, Taipei, Taiwan.

LøFTING, E. C. L. (1973): A survey of the present state of Abies nordmanniana in Denmark, Forstlige Forsoegsvaesen i Danmark 33, 303-326.

Mergen, F., J. Burley and B. A. Simpson (1964): Artificial hybridization in Abies. Der Zuchter 34, 242-251.

Moran, G. F. and A. R. GRIFFIN (1985): Non-random contribution of pollen in polycrosses of Pinus radiata D. Don, Silvae. Genet. 34, 117-121.

Nakamura, R. R. and N. C. Wheeler (1992a): Pollen Competition and Paternal Success in Douglas-Fir, Evolution 46, 846-851.

NAKAMura R. R. and N. C. WheELER (1992b): Self-Fertility Variation and Paternal Success Through Outcrossing in Douglas-Fir. Theor. Appl. Genet. 83, 851-854.

Nielsen, U. B. (1994): Breeding noble fir (Abies procera Rehder) and nordmann fir (Abies nordmanniana (Stev.) Spach) for Christmas trees and greenery in Denmark. Proceedings - Nordic group for tree breeding, Edinburgh, Scotland, 1993, 118-127. Forestry Commission, Edinburgh, Scotland.
NiELSEN, U. B. (2000): Forædling af nordmannsgran og nobilis: Status og muligheder., Pyntegrøntserien 15, $1-54$.

NiElsen, U. B. and G. A. Chastagner (2005): Variation in postharvest quality among Nordmann fir provenances, Hortscience 40, 553-557.

Nyнolm, I. (1986): Håndbog i frøbehandling, Dansk Planteskoleejerforening.

O'Connell, L. M. and K. Ritland (2005): Post-pollination mechanisms promoting outcrossing in a self-fertile conifer, Thuja plicata (Cupressaceae). Canadian Journal of Botany 83, 335-342.

Pakkanen, A., T. Nikkanen and P. Pulkkinen (2000): Annual variation in pollen contamination and outcrossing in a Picea abies seed orchard, Scand. J. Forest. Res. 15, 399-404.

Parantainen, A. and P. Pulkkinen (2003): Flowering and airborne pollen occurrence in a Pinus sylvestris seed orchard consisting of northern clones, Scand. J. Forest. Res. 18, 111-117.

Rhymer, J. M. and D. Simberloff (1996): Extinction by hybridization and introgression, Annual Review of Ecology and Systematics 27, 83-109.

RIESEBERG L. H. (1997): Hybrid origins of plant species, Annual Review of Ecology and Systematics 28, 359-389.

SNEDECOR, G. W. and W. G. Cochran (1980): Statistical Methods, The Iowa State Univ. Press, Ames, Iowa.

StCLAIR, J. B. and W. B. CRITChFIELD (1988): Hybridization of A Rocky-Mountain Fir (Abies Concolor) and A Mexican Fir (Abies Religiosa). Canadian Journal of Forest Research 18, 640-643.

Steiner, W. and H. R. Gregorius (1999): Incompatibility and pollen competition in Alnus glutinosa: Evidence from pollination experiments, Genetica 105, 259-271.

Webber, J. E. and R. A. PAinter (1996): Douglas-fir Pollen Management Manual. Work. Pap. 02/1996. Res. Br., B. C. Min. For.

WRIGHT, J. W. (1976): Introduction to forest genetics, Academic Press, London, UK.

\title{
Spontaneous Hybridization between Pinus sylvestris L. and $P$. mugo Turra in Slovakia
}

\author{
By A. KormutaK ${ }^{1), *)}$, B. Demankova ${ }^{1)}$ and D. GömÖRY ${ }^{2)}$
}

(Received 28 $8^{\text {th }}$ November 2006)

\begin{abstract}
Molecular evidence for spontaneous hybridization between Pinus sylvestris L. and P. mugo Turra in the putative hybrid swarm populations of the species in Slo-

\footnotetext{
1) Institute of Plant Genetics and Biotechnology, Slovak Academy of Sciences, Akademicka 2, P.O.Box 39A, SK-950 07 Nitra, Slovak Republic.

2) Technical University in Zvolen, Faculty of Forestry, T. G. Masaryka 24, SK-960 53 Zvolen, Slovak Republic.
}

*) Corresponding author: E-mail: nrgrkorm@savba.sk
\end{abstract}

vakia was provided based on PCR-RFLP analysis of the cpDNA trnV-trn $\mathrm{H}$ region. Species-specific restriction profiles generated by Hinf I digests of the cpDNA products reliably identified $P$. sylvestris and $P$. mugo haplotypes of the embryos from open pollination. Simultaneous analysis of the respective cpDNA region in megagametophytes and embryos of individual seeds along with needles of a given maternal tree has enabled to score either the $P$. sylvestris or $P$. mugo haplotypes in the embryos illustrating hybridization patterns between the two species. Data obtained in this way indicate a 
relatively extensive hybridization which takes place between $P$. sylvestris and $P$. mugo. The extent of hybridization varied among populations as evidenced by the $41.1-58.7 \%$ proportion of hybrid embryos registered on the locality Habovka, and by the $8.3 \%$ and $2.7 \%$ proportions of hybrid embryos on the localities Tisovnica and Sucha Hora, respectively. The approach itself is recommended as a convenient method for monitoring the hybridization patterns in sympatric zones of the studied pine species.

Key words: Pinus sylvestris L., P. mugo Turra, hybridization, chloroplast DNA, restriction analysis.

\section{Introduction}

Hybrid zones of sympatric or allopatric species may represent intermediate stages in the divergence of populations up to the level of full species (HEwITT, 1988). They have considerable experimental potential for studies of the characters and processes involved in divergence and speciation. Several examples of such zones have been reported in the genus Pinus.

In North America, a spontaneous hybrid of jack pine $(P$. banksiana Lamb.) and lodgepole pine ( $P$. contorta Dougl.) has originated from introgressive hybridization in contact zones of their natural areas in several places of Canada (Moss, 1949; CRITCHFIELD and LitTLE, 1966; Mirov, 1967; ScotTer, 1974; Pollack and DANCIK, 1985; WAGNER et al., 1987, 1989). Introgression between $P$. taeda L. and P. echinata Mill. has been reported to take place near Mtn. Ida of the Montgomery County, Arkansas (EDWARDS-BuRKE et al., 1997). Recently, EPPERSON et al. (2001) reported the introgression between Pinus ponderosa var. scopulorum and P. arizonica in southern Arizona and New Mexico. In Japan, the hybrid swarms were reported in the ecotonal zones of $P$. pumila (Pallas) and P. parviflora Siebold et Zucc. var. pentaphylla (Mayr) in central Honshu and on the island Hokkaido (SENJO et al., 1999; WATANO et al., 2004). Based on isozyme data, $P$. densata is supposed to had evolved as a new species via hybridization between P. tabulaeformis and P. yunnanensis in central China (WANG et al., 1990). The Mediterranean species $P$. brutia Ten. and $P$. halepensis Mill. were found to hybridize extensively in two small districts of the Rhodes island in Greece (PAPAJOANnON, 1936; Boscherini et al., 1994; PANetsos et al., 1997).

However, the oldest known example of introgression between pine species on European continent refers to the hybrid swarm populations of $P$. mugo and P. sylvestris. According to Businsky (1998) the problem of hybrid zones in pines of Central Europe concerns exclusively $P$. sylvestris and $P$. mugo. The existence of spontaneous hybrids between these species has been postulated since the second half of the nineteenth, but discussions regarding their genetic status still persist (Christ, 1864; BRÜGGER, 1886; BERTSCH, 1906). Using allozyme polymorphism at 11 loci NEET-SARQUEDA (1994) has not been able to prove the introgressive hybrid zone hypothesis describing the intermediate form populations of these species in Switzerland as the mixed stands of $P$. sylvestris and $P$. mugo. Conversely, the artificial pollination data by WACHOWIAK et al. (2005) confirmed the compatible hybridological relationship between $P$. sylvestris and $P$. mugo illustrating the possibilities for their hybridization in overlapping zones. However, the recent studies of the authors based on cpDNA markers indicate a strong barrier against interspecific hybridization when $P$. sylvestris is used as a pollen donor (WACHOWIAK et al., 2006a; 2006b). This finding leaves the question of nature and relative proportions of these hybrids in nature opened.

The most recognized places where hybrid swarm populations of $P$. mugo $\times$ P. sylvestris have been reported are Rila Planina and Rodopy in Bulgaria (DoBRINOv, 1965; DoBRINOV and JAHZIDIS, 1971), the Dolina Nowotarska valley in Poland (StAszKIEwiCz and TYszKIEwICZ, 1969; Bobowicz et al., 2000), Swiss Alps (NEET-SARqUEDA et al., 1988) and the Orava region in Slovakia (MUSIL, 1977; VIEWEGH, 1981). Some of these populations were characterized in detail using needle morphology and anatomy (STASZKIEWICZ, 1996; BoBowicz et al., 2000) as well as needle proteins and isoenzymes (PRUS-GLOWACKI and Szweykowski, 1980; PRUs-GLOWACKI et al., 1981). Based on needle traits and phenology of reproductive organs, BoRATYŃSKA et al. (2003) and BoRATYŃSKI et al. (2003) recently reported of gene flow from $P$. sylvestris to $P$. uliginosa and to some extent reciprocally.

Paternal inheritance of chloroplast DNA (cpDNA) in conifers described originally by WAGNER et al. (1987) and confirmed subsequently by NEALE and SEDEROFF (1989) and Mogensen (1996) offers a unique opportunity for analysis of the process of hybridization of pines in molecular terms. The finding of species-specific cpDNA markers for P. mugo and P. sylvestris was a major step in making this opportunity realistic (WACHOWIAK et al., 2000). We have used this approach in analysing the spontaneous hybridization of these species in all the three putative hybrid swarm populations $P$. mugo $\mathrm{x}$ P. sylvestris occurring in Slovakia. Based on needle cross-sections, VIEWEGH (1981) has introduced the name Pinus $\mathrm{x}$ celakovskyorum ASCHERSON et GRAEBNER for the individuals of the hybrid swarm population in Habovka. Statistical treatment of the data on needle size and needle anatomy characteristics in individual trees by three different methods of cluster analysis indicates introgressive hybridization which takes place between the postulated hybrid individuals and the pure species individuals of $P$. sylvestris and $P$. mugo (VIEWEGH and C̆AMBALOVA, 1993). In order to check quantitatively the extent of suspected hybridization, the individual trees of the putative hybrid swarm populations in Slovakia were subjected to the cpDNA analysis using cpDNA of their leaves and seeds from open pollination.

\section{Materials and Methods}

Three putative hybrid swarm populations of $P$. mugo $\mathrm{x}$ $P$. sylvestris growing on peatbogs in Habovka, Tisovnica and Sucha Hora of the Orava region, northern Slovakia, were subjected to molecular analysis. The neighbouring populations of the pure species $P$. mugo Turra in Rohače of the western part of the High Tatras Mts. and P. sylvestris in Hrustin served as a control. All conebearing trees were sampled. Because of temporal varia- 
tion in cone production, different trees were sampled in different years in Habovka. At the tree level, each individual was processed separately using needle cpDNA. At the seed level, each seed of a given tree was processed separately using its megagametophyte and embryo cpDNAs. The number of seeds scored for individual trees ranged between 6 and 11 except for the hybrid swarm in Habovka where only 1 to 3 seeds were analyzed in 2004, mainly because of the poor yield of cones and low quality of seeds. The number of trees representing individual populations together with the number of seeds scored are given in Table 1.

Table 1. - Populations and sample sizes used in the experiment.

\begin{tabular}{|l|l|c|c|c|c|}
\hline Population & Species & Altitude & Year & $\begin{array}{l}\text { Number } \\
\text { of trees }\end{array}$ & $\begin{array}{c}\text { Number } \\
\text { of seeds }\end{array}$ \\
\hline Habovka & $\begin{array}{l}\text { putative } \\
\text { hybrids }\end{array}$ & $815 \mathrm{~m}$ & 2004 & 35 & 70 \\
\hline Habovka & $\begin{array}{l}\text { putative } \\
\text { hybrids }\end{array}$ & $815 \mathrm{~m}$ & 2005 & 13 & 112 \\
\hline Tisovnica & $\begin{array}{l}\text { putative } \\
\text { hybrids }\end{array}$ & $815 \mathrm{~m}$ & 2005 & 20 & 252 \\
\hline $\begin{array}{l}\text { Sucha } \\
\text { Hora }\end{array}$ & $\begin{array}{l}\text { putative } \\
\text { hybrids }\end{array}$ & $765 \mathrm{~m}$ & 2005 & 34 & 325 \\
\hline Rohače & P. mugo & $1450 \mathrm{~m}$ & 2005 & 15 & 120 \\
\hline Hruštin & P.sylvestris & $700 \mathrm{~m}$ & 2005 & 15 & 135 \\
\hline
\end{tabular}

Total DNA was extracted from young needles and seed tissues using the CTAB method of MURRAY and THOMPSON (1980). The $\operatorname{trn} \mathrm{V}$-trn $\mathrm{H}$ region of cpDNA was PCR amplified using the primer pair which consisted of 5'GCTCAGCAAGGTAGAGCACC-3' and 5'-CTTGGTCCACTTGGCTACGT-3' (PARDUCCI and SzMIDT, 1999). DNA amplification was performed at $94^{\circ} \mathrm{C}$ for 4 min followed by 35 cycles at $93^{\circ} \mathrm{C}$ for $1 \mathrm{~min}, 56^{\circ} \mathrm{C}$ for $1 \mathrm{~min}$ and $72^{\circ} \mathrm{C}$ for $2 \mathrm{~min}$. The last strand elongation at $72^{\circ} \mathrm{C}$ was allowed an additional $10 \mathrm{~min}$. To confirm successful amplification of the cpDNA region, $2 \mu \mathrm{l}$ of the PCR products were separated by electrophoresis in $0.8 \%$ agarose gel containing ethidium bromide $\left(0.5 \mathrm{mg} . \mathrm{l}^{-1}\right)$ in $1 \mathrm{x}$ TBE . The DNA fragments were visualized by UV fluorescence. The obtained PCR products were digested with the restriction enzyme Hinf I, which has been found to discriminate the cpDNA of $P$. sylvestris from that of P. mugo (WACHOWIAK et al., 2000; KoRMUTAK et al., 2002). The generated fragments were fractioned electrophoretically in $8 \%$ polyacrylamide gels and $1 \mathrm{x}$ TBE buffer. Electrophoresis was run at $2.5 \mathrm{~V} . \mathrm{cm}^{-1}$ for 3 hours. The gels were stained in $1 \mathrm{x}$ TBE with $\operatorname{EtBr}\left(0.5 \mathrm{mg} . \mathrm{l}^{-1}\right)$.

In the population Habovka, the proportions of progenies from conspecific and interspecific crosses (as assessed by the comparison of maternal and pollen haplotypes) were tested against the random-mating expectations using the $\chi^{2}$-test. The heterogeneity of the proportions of hybrid progenies among maternal trees was tested using the $\chi^{2}$-test. Because of small sample sizes, the distribution of the $\chi^{2}$-statistics was derived from 10000 randomizations.

\section{Results}

The species-specific nature of $\operatorname{trn} \mathrm{V}$-trn $\mathrm{H} / H i n f$ I restriction profiles of $P$. sylvestris and $P$. mugo cpDNAs is

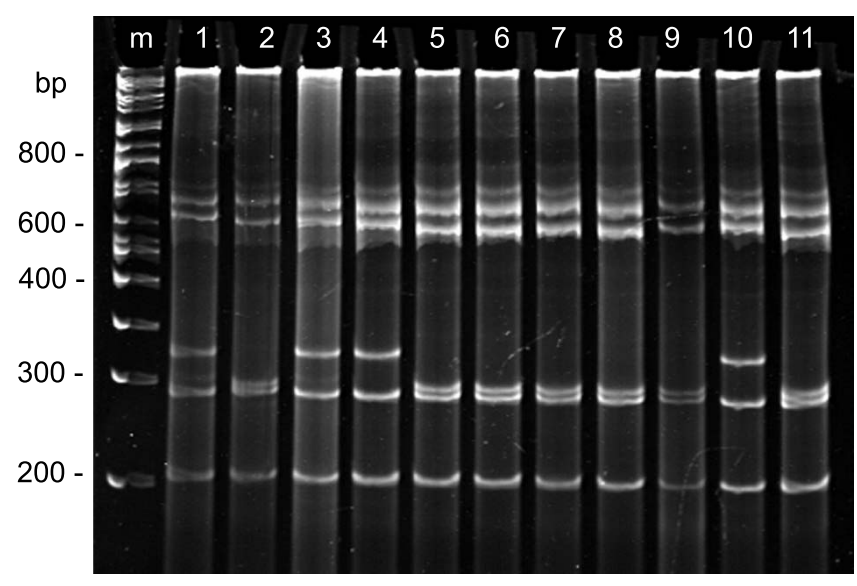

Figure 1. - trnV-trn $\mathrm{H} / H i n f$ I restriction profiles illustrating gene flow between $P$. sylvestris and $P$. mugo; $\mathrm{m}-$ size marker, lane $1-P$. sylvestris needles, lane $2-P$. mugo needles, lanes 3 - 11 - embryos originating from the same tree and exhibiting either $P$. mugo (lanes $5-9,11$ ) or $P$. sylvestris haplotype (lanes $3,4,10)$.

based on differential occurrence of the $320 \mathrm{bp}$ and 300 bp fragments, the former being typical for $P$. sylvestris, the latter for $P$. mugo. The remaining fragments of 750 , 650,280 and $200 \mathrm{bp}$ size are uniformely shared by both species (Fig. 1, lanes 1-2).

No variation between individual trees of putative pure species $P$. mugo and $P$. sylvestris was observed. Identical were also the restriction profiles of needles and megagametophytes of a given tree. Under these conditions, a simultaneous analysis of the respective cpDNA region using needles of a given tree along with the megagametophytes and embryos of individual seeds has enabled to score either $P$. mugo or $P$. sylvestris cpDNA haplotypes in the embryos (Fig. 1). This resulted in partitioning of individual seeds of a given tree according to the cpDNA haplotype of their embryos. The occurrence of embryos of $P$. mugo haplotype on a tree of $P$. sylvestris haplotype or vice versa was taken as an unumbiguous evidence of hybridization event between $P$. sylvestris and $P$. mugo.

The data obtained in this way are summarized in Table 2. It follows from the table that on the locality Habovka, the proportions of trees with the P. sylvestris and P. mugo haplotypes were $50.0 \%$ each. It is this population where the most extensive hybridization takes place as evidenced by $41.1 \%$ of hybrid embryos $P$. mugo $\times$ P. sylvestris recorded in 2004 along with $55.6 \%$ of hybrid embryos of reciprocal combination. Comparable situation was found also in 2005 except that introgression of $P$. sylvestris into $P$. mugo prevailed this year over the hybridization of Pinus sylvestris $\mathrm{x}$ $P$. mugo. Such proportions of hybrid progenies do not deviate significantly from the proportions expected under random mating between species $\left(\chi^{2}=1.03, \mathrm{P}>\right.$ $0.05 ; 2.47, \mathrm{P}>0.05$ and $3.09, \mathrm{P}>0.05$ with $3 \mathrm{df}$ for 2004 , 2005 and pooled samples from both years, respectively). Maternal trees with both maternal haplotypes differed significantly in the proportions of hybrid progenies in 2004 and in 2005 (Table 3). The observed proportions of hybrids ranged from 0 to $100 \%$ in both maternal species. The hybrid swarm populations in Tisovnica and Sucha Hora differed in this respect considerably. We have not 
Table 2. - Gene flow between P. mugo and P. sylvestris as revealed in their hybrid swarm populations and in populations of pure parental species.

\begin{tabular}{|c|c|c|c|c|c|c|c|}
\hline \multirow[t]{2}{*}{ Locality } & \multirow[t]{2}{*}{ Year } & \multicolumn{2}{|c|}{ Trees } & \multirow{2}{*}{$\begin{array}{c}\text { Total } \\
\text { number } \\
\text { of } \\
\text { embryos } \\
\text { scored }\end{array}$} & \multicolumn{2}{|c|}{$\begin{array}{c}\text { Embryo } \\
\text { haplotype }\end{array}$} & \multirow{2}{*}{$\begin{array}{c}\text { Percentage } \\
\text { of hybrid } \\
\text { embryos }\end{array}$} \\
\hline & & $\begin{array}{l}\text { Needle/ } \\
\text { megagamet. } \\
\text { haplotype }\end{array}$ & Number & & $\begin{array}{l}P . \\
\text { mugo }\end{array}$ & $\begin{array}{l}P . \\
\text { sylvestris }\end{array}$ & \\
\hline Habovka & 2004 & $\begin{array}{l}\text { P. mugo } \\
\text { P. sylvestris }\end{array}$ & $\begin{array}{l}18 \\
17\end{array}$ & $\begin{array}{l}34 \\
36\end{array}$ & $\begin{array}{l}20 \\
20\end{array}$ & $\begin{array}{l}14 \\
16\end{array}$ & $\begin{array}{l}41.1 \\
55.6\end{array}$ \\
\hline Habovka & 2005 & $\begin{array}{l}\text { P. mugo } \\
\text { P. sylvestris }\end{array}$ & $\begin{array}{l}6 \\
7 \\
\end{array}$ & $\begin{array}{l}46 \\
66 \\
\end{array}$ & $\begin{array}{l}19 \\
34 \\
\end{array}$ & $\begin{array}{l}27 \\
32 \\
\end{array}$ & $\begin{array}{l}58.7 \\
51.5 \\
\end{array}$ \\
\hline Tisovnica & 2005 & $\begin{array}{l}\text { P. mugo } \\
\text { P. sylvestris }\end{array}$ & $\begin{array}{c}24 \\
0\end{array}$ & 252 & 231 & 21 & 8.3 \\
\hline $\begin{array}{l}\text { Sucha } \\
\text { Hora }\end{array}$ & 2005 & $\begin{array}{l}\text { P. mugo } \\
\text { P. sylvestris }\end{array}$ & $\begin{array}{c}34 \\
0\end{array}$ & 325 & 316 & 9 & 2.7 \\
\hline Rohače & 2005 & P. mugo & 15 & 120 & 120 & 0 & 0 \\
\hline Hruštin & 2005 & P. sylvestris & 15 & 135 & 0 & 135 & 0 \\
\hline
\end{tabular}

Note: Percentage of hybrid embryos expressed as the number of embryos of different haplotype per total number of embryos of all mother trees of a given haplotype.

detected $P$. sylvestris cpDNA haplotype in any of the sampled trees on these localities. As a consequence, only $P$. mugo $\mathrm{x} P$. sylvestris hybrids were registered here reaching the average extent of $8.3 \%$ in Tisovnica and $2.7 \%$ in Sucha Hora. Nevertheless, like in Habovka, individual maternal trees significantly differed in the proportions of hybrid progenies (Table 3).

As expected, the individuals of pure species $P$. mugo from Rohače exhibited exclusively $P$. mugo cpDNA hap-

Table 3. $-\chi^{2}$-test of heterogeneity of proportions of hybri progenies among trees in individual populations.

\begin{tabular}{|l|l|l|l|l|}
\hline Population & Year & Maternal haplotype & $\chi^{2}$ & $P$ \\
\hline Habovka & 2004 & P. mugo & 25.19 & 0.9825 \\
& & P. sylvestris & 23.85 & 0.9804 \\
& 2005 & P. mugo & 21.03 & 0.9921 \\
& & P. sylvestris & 28.26 & 0.9951 \\
\hline Tisovnica & 2005 & P. mugo & 91.79 & 0.9999 \\
\hline Sucha Hora & 2005 & P. mugo & 68.40 & 0.9960 \\
\hline
\end{tabular}

lotype and produced only seeds of intraspecific crosses. The same is true of the pure species population $P$. sylvestris from Hrustin, where individuals were of $P$. sylvestris cpDNA haplotype at both the tree and seed levels (Table 2).

\section{Discussion}

Scots pine and mountain dwarf pine are taxonomically related species of the subgenus Diploxylon (Hard Pines) occupying common position within the group Lariciones according to SHAW (1914) and/or within the section Eupitys and Pinus according to PILGER (1926) and PrICE et al. (1998). LiTTLE and CRITCHFIELD (1969) placed these pines in the section Pinus, subsection Sylvestres Loud. Based on artificial hybridization experiments, DUFFIELD (1952) included both these species in Group X, indicating some hybridological affinity between them. It was maintained since the beginning of the last century that the spontaneous hybridization between $P$. sylvestris and $P$. mugo is rather rare (PETERSEN, 1903). In connection to this, CHRISTENSEN and DAR (1997) have mentioned five types of obstacles preventing mutual hybridization between these species in nature. The differences in anthesis, in altitudinal and ecological ranges along with reduced number and viability of hybrid seeds and failure of the hybrids to become established are supposed to be responsible for a partial reproductive isolation of $P$. sylvestris and P. mugo. Nevertheless, rare as they appear, the existence of spontaneous hybrids of these species is generally acknowledged. The experimental evidence is primarily based on morphometric analysis of the hybrid swarm populations using phenotypic appearance of the trees (DOBRINOV and JAHZIDIS, 1971), bark, cone and needle characteristics, including needle crosssections (MARCET, 1967; CHRISTENSEN and DAR, 1997; STASZKIEWICZ, 1996; BoBOwICZ et al., 2000; BoRATYŃSKA et al., 2003) and phenology of reproductive organs (BoRATYŃSKI et al., 2003). Biochemically such populations were characterized in terms of needle proteins and isoenzymes (PRUS-GlowACKI and StePHAN, 1998; PRUSGlowACKI and SzWEYKOWSKI, 1980; PRUs-GlowACKI et al., 1981). Based on these data, the distance dendrograms and hybridity indexes have been derived supporting hybrid nature of $P$. sylvestris and $P$. mugo swarm populations. Paternal inheritance of cpDNA in conifers offers a more straightforward approach in screening introgressive processes at seed level. The difference in trnL-trnF intergenic spacer region of $P$. elliottii var. elliottii and $P$. caribaea var. hondurensis cpDNAs allowed to distinguish the hybrid progeny of these species from intraspecific and self progenies of the maternal species (SHEPHERD and HENRY, 2002). The same cpDNA marker was used by CHEN et al. (2002) in verifying putative hybrids $P$. echinata $\times P$. taeda. Using $B c l$ I digest of the entire cpDNA, FilPPULA et al. (1992) were able to discriminate between $P$. sylvestris and $P$. mugo but not to prove the hybrid nature of suspected hybrid population $P$. mugo $\times$ P. sylvestris of the French Alps origin.

The species-specific marker for these species described by WACHOWIAK et al. (2000) refers to the variation in non-coding region between the $\operatorname{trn} \mathrm{F}$ and $\operatorname{trn} \mathrm{L}$ genes of cpDNA. The Dra I and Hinf I digests of the respective 
PCR product generate restriction patterns which reliably discriminate between $P$. sylvestris and $P$. mugo. The paternal inheritance of this marker has subsequently been proved by the authors on the example of reciprocal crosses between the parental species (WACHOWIAK et al., 2005). In presented study we used the $\operatorname{trn} \mathrm{V}$-trn $\mathrm{H}$ region of cpDNA that was found to differ in P. sylvestris and P. mugo after digestion with Hinf I and which did not exhibit intraspecific variation (KORMUTAK et al., 2002). In combination with the trnF-trnL/Dra I and Hinf I restriction patterns it broadens the chances for evaluation of events connected with gene flow between these species. Using this marker it was possible to provide direct molecular evidence for spontaneous hybridization between $P$. sylvestris and $P$. mugo at the seed level only. The opinions of some authors differ concerning the frequency of hybridization between these species. WACHOWIAK et al. (2005) have for example reported of incompatible nature of $P$. mugo $\times$ P. sylvestris combination. According to the authors, the reciprocal cross has also exhibited low compatibility between the parental species as evidenced by the yield of 36 empty seeds and 4 filled seeds obtained within the two mother trees of $P$. sylvestris. The outlined hybridological status of $P$. mugo $\times$ P. sylvestris crossing has repeatedly been confirmed by WACHOWIAK et al. (2006b) using 12 different clones of the paternal species. However, the involvement into artificial pollination of two additional clones of P. sylvestris (Hasl E 203, Schl 77/1) resulted in $35.6 \%$ and $56.8 \%$ yields of 1 -year-old seedlings. It is worth of noting that our attempt with artificial hybridization of $P$. sylvestris and $P$. mugo resulted in relatively high yields of filled seeds ranging between $70.0 \%$ and $96.3 \%$ in P. mugo x P. sylvestris and between $13.5 \%$ and $83.4 \%$ in the reciprocal combination (KORMUTAK et al., 2005). This indicates fairly high hybridological affinity between the parental species. Presented restriction analysis data confirmed a relatively extensive gene flow between them also in zones of their sympatry. The detected frequency of $P$. mugo $\times$ P. sylvestris embryos (51.2\%) and reciprocal ones $(52.9 \%)$ in Habovka favours the isozyme based conclusion by PRUS-GLOWACKI and SzWEYKOWSKI (1983) about frequent occurrence of these hybrids in nature. We may only speculate whether reduced viability of hybrid seeds and/or low survival rate of hybrid individuals were the reasons of low frequency hybridization between $P$. sylvetris and $P$. mugo observed by CHRISTENSEN (1987) on the morphological basis. This figure differs considerably on individual localities studied, most probably due to the variable proportions of $P$. sylvestris and $P$. mugo individuals and their spatial distribution on these localities. Under conditions of the overlapping flowering of both parental species, the prevalence of $P$. sylvestris individuals has ensured a higher probability of pollination of $P$. uliginosa megastrobili by the pollen of prevailing species (BORATYŃSKI et al., 2003). We suppose that reduced occurrence of $P$. sylvestris trees accounts for the low frequency of hybridization of the species with $P$. mugo at the localities Tisovnica and Sucha Hora. The detrimental effect of climatic conditions cannot be excluded as well, as evidenced by the annual variation in frequency of intro- gression between the parental species at the locality Habovka in 2004 and 2005.

There was a significant variation in the proportion of hybrid progenies among individual trees in all hybrid swarm populations. One possible cause is the flowering phenology. Regarding the fact that $P$. sylvestris flowers earlier than P. mugo (BoRATYŃSKI et al., 2003), only a small portion of trees of both maternal species is synchronized phenologically. The other reason might be genetic. Because of introgression, some trees with the $P$. sylvestris haplotype may contain a considerable portion of $P$. mugo genes and vice versa, so that they may be more prone to hybridization.

Irrespective of the variable extent of hybridization, the process was proved convincibly to take place between $P$. sylvestris and $P$. mugo in all the three putative hybrid populations in Slovakia. The method itself was shown to share a high diagnostic potential for scoring spontaneous hybridization between these species at seed level. However, it does not allow identification of the hybrid trees unless a species-specific marker for $P$. sylvestris and P. mugo mtDNAs is available.

\section{Acknowledgement}

This work was supported by Science and Technology Assistance Agency under contract No. APVT-51/004-004.

\section{References}

Bertsch, K. (1906): Die Pinus - Formen in Federseeried. Botanische Zeitschrift für Systematik 12: 7-12.

Bobowicz, M. A., B. R. Stephan and W. Prus-Glowacki (2000): Genetic variation of $\mathrm{F}_{1}$ hybrids from controlled crosses between Pinus montana var. rostrata and Pinus sylvestris in anatomical needle traits. Acta Societatis Botanicorum Poloniae 69: 207-214.

BoratyŃska, K., A. Boratyński and A. LeWANDOWski (2003): Morphology of Pinus uliginosa (Pinaceae) needles from populations exposed to and isolated from the direct influence of Pinus sylvestris. Botanical Journal of the Linnean Society 142: 83-91.

Boratyński, A., K. Boratyńska, A. Lewandowski, Z. GOLAB and KICIŃSKI, P. (2003): Evidence of the possibility of natural reciprocal crosses between Pinus sylvestris and $P$. uliginosa based on the phenology of reproductive organs. Flora 198: 377-388.

Boscherini, G., M. Morgante, P. Rossi and G. G. VenDRAMIN (1994): Allozyme and chloroplast DNA variation in Italian and Greek populations of Pinus leucodermis. Heredity 73: 284-290.

BRÜGGER, C. G. (1886): Mittheilungen über neue und kritische Pflanzenformen. Erste Serie. Jahresbericht Naturwissentschaftlicher Gesellschaft Graubündens 29: $49-178$.

Businsky, R. (1998): Pinus mugo complex in former Czechoslovakia - taxonomy, distribution, hybrid populations and endangerment. Report of Czechoslovak Botanical Society, Prague 33: 29-52.

Chen, J., C. G. TAuer and Y. Huang (2002): Paternal chloroplast inheritance patterns in pine hybrids detected with trnL-trn $\mathrm{F}$ intergenic region polymorphism. Theoretical and Applied Genetics 104: 1307-1311.

Christ, H. (1864): Beträge zur Kenntnis europäischer Pinus-Arten. III. Die Formen der Pinus sylvestris des Ober-Engadins (Ctn. Graubünden). Flora 22: 147-160. 
Christensen, K. I. (1987): A morphometric study of the Pinus mugo Turra complex and its natural hybridization with $P$. sylvestris L. (Pinaceae). Fedes Repert 98: 623-635.

Christensen, K. and G. H. Dar (1997): A morphometric analysis of spontaneous and artificial hybrids of Pinus mugo $\mathrm{x}$ P. sylvestris (Pinaceae). Nordic Journal of Botany 17: 77-86.

CRitchfield, W. D. and E. L. LitTle (1966): Geographic distribution of the pines of the world. USDA Forest Service Miscellaneous Publication 991: 1-97.

Dobrinov, I. (1965): Study on natural hybrids between Pinus sylvestris and Pinus mugo var. mughus in Bulgaria. Naucne Trudy Lesotechnitscheskogo Instituta $\mathbf{1 3}$ 39-48.

DoBRINOv, I. and G. JAGHIDIS (1971): Spontaneous hybrids between Pinus sylvestris and Pinus mugo in Bulgaria. Gorsko Stopanstvo 11: 28-30.

DufFIELD, J. W. (1952): Relationships and species hybridization in the genus Pinus. Zeitschrift für Forstgenetik und Forstpflanzenzüchtung 1: 93-97.

Edwards-Burke, M. A., J. L. Hamrick and R. A. Price (1997): Frequency and direction of hybridization in sympatric populations of Pinus taeda and P. echinata (Pinaceae). American Journal of Botany 84: 879-886.

Epperson, B. K., F. W. Telewski, A. E. Plovanich-Jones and J. E. GRIMES (2001): Clinal differentiation and putative hybridization in a contact zone of Pinus ponderosa and P. arizonica (Pinaceae). American Journal of Botany 88: 1052-1057.

Filpulla, S., A. E. Szmidt and O. Savolainen (1992): Genetic comparison between Pinus sylvestris and $P$. mugo using isozymes and chloroplast DNA. Nordic Journal of Botany 12: 381-386.

HewitT, G. M. (1988): Hybrid zones - natural laboratories for evolutionary studies. Tree 3: 158-167.

Kormutak, A., B. Vookova, T. Salajova, X.-R. Wang and A. E. SzMidT (2002): Morphometric and genetic analyses of the putative hybrid Pinus sylvestris $\mathrm{x}$ Pinus mugo in Habovka, pp. 29 in Abstracts of IUFRO symposium of population and evolutionary genetics of forest trees, 25-29 August 2002, Stara Lesna, Slovakia.

Kormutak, A., M. Ostrolucka, B. Vookova, A. Pretova and M. FEC̆KOVA (2005): Artificial hybridization of Pinus sylvestris L. and Pinus mugo Turra. Acta Biologica Cracoviensia, Series Botanica 47: 129-134.

LitTle, E. L. and W. B. CRITChFiELD (1969): Subdivisions of the genus Pinus (Pines). U.S. Department of Agriculture, Washington, D.C. Forest Service Micsellaneous Publication No. 1144.

MARCET, E. (1967): Über den Nachweis spontaner Hybriden von Pinus mugo Turra und Pinus sylvestris L. Aufgrund von Nadelmerkmalen. Berichte Schweizer Botanischen Gesellschaft 77: 314-361.

Mirov, N. T. (1967): The genus Pinus. Ronald Press Company, New York.

Mogensen, H. L. (1996): The hows and whys of cytoplasmic inheritance in seed plants. American Journal of Botany 83: 383-404.

Moss, E. H. (1949): Natural pine hybrids in Alberta. Canadian Journal of Research 27: 218-229.

Murray, M. G. and W. F. Thompson (1980): Rapid isolation of high molecular weight DNA. Nucleic Acid Research 8: 4231-4235.

Musil, I. (1977): Needle variation in the complex Pinus mugo and Pinus sylvestris. Preslia (Prague) 19: 1-6.
Neale, D. B. and R. R. Sederoff (1989): Paternal inheritance of chloroplast DNA and maternal inheritance of mitochondrial DNA in loblolly pine. Theoretical and Applied Genetics 77: 212-216.

Neet-Sarqueda, C., A. C. Plumettaz Clot and I. BéchoLEY (1988): Mise en évidence de l'hybridation introgressive entre Pinus sylvestris L. et Pinus uncinata DC. en Valais (Suisse) par deux méthodes multivariées. Botanica Helvetica 98: 161-169.

NeET-SARquedA, C. (1994): Genetic differentiation of Pinus sylvestris L. and Pinus mugo aggr. populations in Switzerland. Silvae Genetica 43: 207-215.

Panetsos, K., A. Scaltsoyiannes, F. A. Aravanopoulis, K. Dounavi and A. Demetrakopoulos (1997): Identification of Pinus brutia Ten., P. halepensis Mill. and their putative hybrids. Silvae Genetica 46: 253-257.

PAPAJOANNON, J. (1936): Über Artbastarde zwischen Pinus brutia Ten. und Pinus halepensis Mill. in NordostChalkidiki, Griechenland. Forstwisschafen Zentralblat 58: 194-205.

PARDUCCI, L. and A. SzMidT (1999): PCR-RFLP analysis of cpDNA in the genus Abies. Theoretical and Applied Genetics 98: 802-808.

Petersen, O. G. (1903): Formentlige Bastarder mellem Skovfyr og Bjergfyr. Tidsskr. Skovvaesen 15B: 171-184.

PILGER, R. (1926): Genus Pinus, pp. 93-113. In: Die natürlichen Pflanzenfamilien, vol. 3. Gymnospermae, edited by A. Engler and K. PRANTL, Wilhelm Engelmann, Leipzig.

Pollack, J. C. and B. P. DANCIK (1985): Monoterpene and morphological variation and hybridization of Pinus contorta and P. banksiana in Alberta. Canadian Journal of Botany 63: 201-210.

Price, R. A., A. Liston and S. H. Strauss (1998): Phylogeny and systematics of Pinus, pp. 49-68. In: Ecology and biogeography of Pinus, edited by D. M. RICHARDSON, Cambridge University Press.

Prus-GlowaCKI, W. and J. SzWEYKowsKI (1980): Serological characteristics of some putative individuals from a Pinus sylvestris $\times$ Pinus mugo hybrid swarm population. Acta Societatis Botanicorum Poloniae 49: 127-142.

Prus-GlowACKI, W. and J. SzWEYKowsKi (1983): Studies on isoenzyme variability in populations of Pinus sylvestris L., Pinus mugo Turra, Pinus uliginosa Neumann and individuals from a hybrid swarm population. Bulletin de la Societe des Amis des Sciences et des Lettres de Poznań (Series D Sciences Biologiques) 22 $108-122$.

Prus-Glowacki, W., J. SAdowski, J. Szweykowski and I. WiATroszAK (1981): Quantitative and qualitative analysis of needle antigens of Pinus sylvestris, Pinus mugo, Pinus uliginosa and Pinus nigra and of some individuals from hybrid swarm population. Genetica Polonica 22: 447-454.

Prus-Glowacki, W. and S. H. Stephan (1998): Immunochemical and isoenzymatic characterization of hybrids from controlled crosses between Pinus montana var. rostrata and Pinus sylvestris. Forest Genetics 5: 155-163.

ScotTeR, G. W. (1974): Distribution of pine (Pinus ssp.) in the south Nahanni and Flat Rivers region, northwest territories. Canadian Journal of Forest Research 4 $555-557$.

Senjo, M., K. Kimura, Y. Watano, K. Ueda and T. Shimizu (1999): Extensive mitochondrial introgression from Pinus pumila to $P$. parviflora var. pentaphylla (Pinaceae). Journal of Plant Research 112: 97-105. 
Shaw, G. R. (1914): The genus Pinus. Arnold Arboretum Publication No. 5, Houghton Mifflin Corporation, Boston.

SHEPHERD, M. and R. HENRY (2002): Identifizierung von Hybriden von Pinus elliottii var. elliottii $\times$ P. caribaea var. hondurensis mittels Chloroplasten trn L-F intergenischen Abständen. Silvae Genetica 51: 273-277.

Staszkiewicz, J. (1996): Natural hybrids of Pinus mugo $\mathrm{x}$ P. sylvestris (Pinaceae) in Tatra Mts. Fragmenta Floristica et Geobotanica, Series Polonica 3: 23-30.

Staszkiewicz, J. and M. TYszKiewicz (1969): Natural hybrids of Pinus mugo Turra $\mathrm{x}$ Pinus sylvestris L. in Nowy Targ valley. Fragmenta Floristica et Geobotanica 15: $187-212$.

Viewegh, J. (1981): Variability of the hybrid swarms Pinus mugo x Pinus sylvestris on peat-bog in Zuberec, Orava. Folia Dendrologica 8: 41-59.

VieweGH, J. and C̆AMBALOVA, H. (1993): Variability of hybrid swarm Pinus $\mathrm{x}$ celakovskiorum A. et Gr. processed with some cluster analysis methods. Biologia (Bratislava) 48: 39-44.

WACHOWIAK, W., K. LEŚNIEWICZ, I. J. ODRZYKOSKI, H. Augustyniak and W. Prus-Glowacki (2000): Speciesspecific cpDNA markers useful for studies on the hybridization between Pinus mugo and P. sylvestris. Acta Societatis Botanicorum Poloniae 69: 273-276.

WACHOWIAK, W., A. LeWANDOWSKI and W. PRUs-GlOWACKI (2005): Reciprocal controlled crosses between Pinus sylvestris and $P$. mugo verified by a species-specific cpDNA marker. Journal of Applied Genetics 46: 41-43.

WACHOWIAK, W., I. OdRzYKoski, L. MYczKo and W. PRUSGLOWACKI (2006a): Lack of evidence on hybrid swarm in the sympatric population of Pinus mugo and $P$. sylvestris. Flora 201: 307-316.

Wachowiak, W., B. R. Stephan, I. Schulze, W. PrusGLOWACKI and B. ZIEGENHAGEN (2006b): A critical evaluation of reproductive barriers between closely related species using DNA markers - a case study in Pinus. Plant Systematics and Evolution 257: 1-8.

Wagner, D. B., G. R. Furnier, M. A. Saghai-Maroof, S. M. Williams, B. P. DanciK and R. W. Allard (1987): Chloroplast DNA polymorphism in lodgepole pines and jack pines and their hybrids. Proceeding of the National Academy of Sciences U.S.A. 84: 2097-2100.

Wagner, D. B., D. R. Govindaraju, C. W. Yeatman and J. A. Pitel (1989): Paternal chloroplast DNA inheritance in a diallel cross of jack pine (Pinus banksiana Lamb.). The Journal of Heredity 80: 483-485.

WANG, X.-R., A. E. SzMidt, A. LeWANDOWski and Z.-R. WANG (1990): Evolutionary analysis of Pinus densata Masters, a putative tertiary hybrid. Theoretical and Applied Genetics 80: 635-640.

WATANO, Y., A. KANAI and N. TANI (2004): Genetic structure of hybrid zones between Pinus pumila and P. parviflora var. pentaphylla (Pinaceae) revealed by molecular hybrid index analysis. American Journal of Botany 91: 65-72.

\title{
Primer Note: A New Set of Highly Polymorphic Nuclear Microsatellite Markers for Nothofagus nervosa and Related South American Species
}

\author{
By P. Marchelli ${ }^{\left.1),{ }^{*}\right)}$, H. Caron ${ }^{2)}$, M. M. AzPilicueta ${ }^{1)}$ and L. A. Gallo ${ }^{1)}$
}

(Received 13 $3^{\text {th }}$ March 2007)

\begin{abstract}
Nothofagus is the main component of southern South American temperate forests. Overexploitation in the past has led to the loss of $40 \%$ of the original distribution range. Genetic diversity as well as biological processes shaping the distribution of the genetic variation (e.g. gene flow) constitutes basic knowledge for the implementation of conservation measures and for the definition of Evolutionary Significant Units. Nuclear microsatellites are the marker of choice for gene flow and fine-scale genetic structure studies. We enlarged a

1) Forest Genetic Unit, INTA EEA Bariloche, CC 277, 8400 Bariloche, Argentina.

2) INRA-UMR BIOGECO, 69 route d'Arcachon, 33612 Cestas cedes, France.

*) Correspondence author: PaUla Marchelli, INTA EEA Bariloche, Unidad de Genética Forestal, CC 277, 8400 Bariloche, Argentina. Fax: 00542944 422731. Email: pmarchelli@ bariloche.inta.gov.ar.
\end{abstract}

previous set of microsatellites (SSRs) for South American Nothofagus species, with special concern to Nothofagus nervosa (Phil.) Dim. et Mil. Five new SSRs are presented with allele numbers up to 12 in a single population. The primers transferred well to five related species (N. obliqua (Mirb.) Oerst, N. glauca (Phil.) Krasser, $N$. dombeyi (Mirb.) Oerst , N. pumilio (Poepp et Endl.) Krasser and $N$. antarctica (G. Forster) Oerst, with allele numbers up to 11 . The high level of polymorphism promises a sufficient power for gene flow and parentage analyses.

Key words: Nothofagus, microsatellites, South America, gene flow, fine-scale genetic structure.

\section{Introduction}

Nothofagus is the dominant genus of southern South American temperate forests, with a total of ten endemic species. In the last century, over-exploitation, over 